Revista Investigaciones Turísticas, no 12, pp. 50-72

ISSN: 2174-5609

DOI. http://dx.doi.org/10.14198/INTURI2016.12.03

गT Investigaciones

verancoses TURISTICAS

\title{
Reflexões sobre conceitos e definições atinentes ao turismo envolvendo comunidades indígenas
}

\author{
Sandra Dalila Corbari \\ corbari91@hotmail.com
}

Miguel Bahl

migbahl@ufpr.br

Silvana do Rocio de Souza

silvanasouza.tur@gmail.com

Universidade Federal do Paraná, Brasil

\section{RESUMO}

O turismo foi fortemente influenciado pelo modelo Fordista de produção e consumo, porém na década de 1980 surgiu o Pós-Fordismo, impactando também nessa atividade. Surgiram, assim, diversos "novos turismos" que promoviam experiências autênticas, dentre elas o turismo cultural, o turismo étnico, o turismo indígena e o turismo em áreas indígenas. Desse modo, com a presente pesquisa buscou-se, através da análise bibliográfica, explorar as especificidades desses tipos e segmentos turísticos que permeiam a relação entre o turismo e as comunidades indígenas. Verificou-se com a pesquisa que os investigadores adotam diversos tipos de conceitos para cada tipo de turismo, evidenciando uma diferenciação, porém ao mesmo tempo uma inter-relação entre eles. Por constatarem-se as diferenças existentes de conceituação, foi proposta uma divisão dos segmentos, conforme características descritas pelos autores, a qual apresenta-se em forma de esquema e também discorrida textualmente. Compreende-se que a discussão conceitual é importante para a construção da teoria sobre o turismo, mas também para o próprio entendimento de suas especificidades.

Palavras-chave: Turismo e sociedade. Turismo étnico. Turismo indígena. Comunidades indígenas. Conceituação. 


\title{
Reflections on concepts and definitions regarding tourism involving indigenous communities
}

\begin{abstract}
Tourism has been strongly influenced by the Fordist model of production and consumption, but in the 1980s the Post-Fordism emerged impacting the touristic activity. Emerged the "new tourisms" promoting authentic experiences, including cultural tourism, ethnic tourism, "indigenous tourism" and tourism in indigenous areas. Thus, this research, through literature review, explores the specifics of these typologies and tourist segments that are based in the relationship between tourism and indigenous communities. It has been found that researchers adopt various types of concepts for each type of tourism, showing a differentiation, but at the same time an interrelation between them. To clarify the diferences between concepts, a segmentation is proposed following the characteristics described by the authors. Such division is presented in a visual graph and in textual format. This conceptual discussion is important for the construction of tourism theory and the understanding of its specificities.
\end{abstract}

Keywords: Tourism and society. Indigenous ethnic tourism. Indigenous communities. Conceptualization.

\section{INTRODUÇÃO}

A atividade turística foi fortemente influenciada pelo modelo fordista de produção em consumo, promovendo o denominado turismo de massa, principalmente no segmento de sol e praia (Torres, 2002). Entretanto, segundo esse autor, a homogeneização e uniformização dos destinos turísticos foram debilitadas com o surgimento de um modelo em resposta ao Fordismo, o Pós-Fordismo. Tal modelo representou um movimento do turismo de massa para um turismo mais diversificado, com uma maior gama de produtos e surgimento de segmentos turísticos que se adequavam a diferentes tipologias de turistas, a novas demandas que almejavam por experiências distintas e autênticas (Pereiro Pérez et al., 2012; Torres, 2002; Santana Talavera, 2003).

Desse modo, surgiram a partir do final da década de 1980 diversos "novos turismos", em que se promoviam experiências autênticas junto à natureza, à cultura e à comunidade ou em uma combinação desses elementos (Santana Talavera, 2003). Entre esses novos segmentos encontram-se o turismo cultural, o turismo étnico ou etnoturismo e o turismo indígena, os quais possuem conceitos que se inter-relacionam e que, por vezes, são defendidos sob diferentes óticas pelos pesquisadores, promovendo uma gama de conceitos para um mesmo tipo de turismo. Assim, verificou-se haver, na literatura sobre o turismo, inúmeras nomenclaturas, algumas oriundas dos planos governamentais ou de organizações internacionais, outras construídas a partir da reflexão e da experiência teórica e da prática dos pesquisadores. Nesse sentido, percebeu-se a necessidade de realizarem-se duas ações. Em um primeiro momento, era necessário averiguar quais seriam os segmentos ou as características de gestão estabelecidos em comunidades indígenas brasileiras, através da análise bibliográfica e, especialmente, segundo a visão de pesquisadores ou dos próprios indígenas, para isso foram utilizadas como corpus de pesquisa as teses e dissertações brasileiras, publicadas entre 1999 e 2012 disponíveis no Banco de Teses e Dissertações da 
Coordenação de Aperfeiçoamento de Pessoal de Nível Superior (CAPES), totalizando 14 pesquisas.

Em um segundo momento, sentiu-se a necessidade de estabelecer uma conceituação própria, desse modo, após a apresentação da análise bibliográfica, apresenta-se uma proposta de divisão dos segmentos e tipos de turismo conforme suas características. Desse modo, apresenta-se, primeiramente a revisão de literatura, abordando-se as principais nomenclaturas utilizadas pelos estudiosos. Em seguida apresentam-se as nomenclaturas utilizadas pelos pesquisadores brasileiros e indígenas e, na sequência, um esquema conceitual criado pelos autores. Ao final, tem-se a conclusão e as referências bibliográficas.

\section{O PÓS-TURISMO, O PÓS-TURISTA E A SEGMENTAÇÃO DO TURISMO}

Conforme preliminarmente mencionado, o turismo foi fortemente influenciado pelo modelo fordista de produção e consumo, modelo este que se intensificou no período entre o final da Segunda Guerra Mundial até a década de 1970 (Harvey, 1996). Para Torres (2002) as principais características que confirmam a existência do modo de produção fordista no turismo são: o consumo coletivo, com concentração de visitantes em uma mesma localidade; perfil padrão de consumidores, verificado através da presença em massa de uma determinada tipologia de turistas; turismo de massa, principalmente no segmento de sol e praia; estandardização dos produtos turísticos, visível a partir da proliferação de pacotes e empreendimentos internacionais.

O ciclo de vida dos destinos os tornou em fantasias monocolores e homogêneas, sendo que alguns destinos se diferenciavam por ínfimos pedaços de originalidade, presentes em danças, celebrações ou pratos estereotipados (Santana Talavera, 2003). Esse autor aponta que se revelavam custos e impactos não previstos nos destinos, uma alta competitividade entre os mesmos, uma ampla demanda exigente e um globo cada vez mais estreito por conta da facilidade de deslocamento e similaridade de ideias. Porém, na década de 1970, surgiu o Pós-Fordismo (Harvey, 1996; Pereiro Pérez et al., 2012) que ocasionou, no turismo, um movimento do turismo de massa para uma atividade turística mais diversificada, com diferenciação de produtos e surgimento de novos segmentos turísticos, fixando o "olhar do turista" sobre a paisagem ambiental, cultural e social (Pereiro Pérez et al., 2012; Torres, 2002; Santana Talavera, 2003). Pereiro Pérez et al. (2012) ressaltam que, com este modelo, foi possível entender melhor a valorização do patrimônio cultural, a transformação de eventos em festivais, a nova ética ecológica do turismo, o turismo de negócios, entre outros. Pode-se afirmar que a nova demanda passou a transformar qualquer espaço em um espaço turístico e "turistifica" qualquer tema.

Molina (2003) apresenta o pós-turismo e o caracteriza como tendo alteração das preferências da demanda, que busca novas experiências, conduzindo à ampliação do mercado turístico e novas expectativas por parte das comunidades receptoras que passam a almejar os benefícios do turismo, tendo em vista que o modelo turístico anterior não trouxe vantagens para o desenvolvimento social das comunidades.

Considerou-se esse debate inicial ser pertinente, pois ao abordar distintos segmentos turísticos é necessário compreender que os mesmos surgiram em decorrência de uma nova necessidade, através da pressão da demanda por experiências diferentes e autênticas, assim como defendido por Santana Talavera (2003). Para o referido autor, esses novos produtos 
deveriam possuir a qualidade de serem, ao menos aparentemente, ofertados a uma minoria, serem economicamente viáveis, e não serem causadores dos mesmos efeitos do turismo de massa.

Assim, desde o final da década de 1980 assistiu-se a aparição de uma gama de "novos turismos", que se apresentam como formas diferentes de se praticar o turismo e de promoverem uma experiência satisfatória ao cliente, a experiência autêntica junto à natureza, à cultura, à comunidade ou em uma combinação dos mesmos (Santana Talavera, 2003). No caso do turismo envolvendo comunidades indígenas, do qual o presente artigo trata, na Austrália comumente é denominado turismo indígena ou aborígene, nos Estados Unidos denomina-se first nations tourism ou também turismo antropológico ou tribal (Zeppel, 2006). No Brasil, ele é comumente denominado turismo indígena, turismo étnico, turismo em Terras Indígenas, dentre outros que se apresentam a seguir.

\section{O TURISMO CULTURAL}

O segmento de turismo cultural é visto por Pereiro Pérez (2009) como sendo parte do modelo pós-fordista, uma vez que esse segmento seria uma alternativa ao turismo de sol e praia. $\mathrm{O}$ autor cita que o turismo cultural tem se convertido em uma etiqueta de distinção social, contribuindo para a construção de identidades nas suas práticas rituais. Apesar do caráter de construção identitária, o turismo cultural também é apontado como um agente classificador e categorizador que cria um produto onde os artistas são cativos dos empresários (Ryan, 2005).

Costa (2009) e Faria (2008) conceituam o turismo cultural como um segmento que, por meio de apreciação, vivência e experimentação direta do patrimônio cultural, material ou imaterial e utilizando-se da comunicação interpretativa, proporciona aos visitantes a participação ativa na construção do conhecimento acerca do patrimônio cultural e de seu contexto histórico e social. A esse conceito Pereiro Pérez (2009) acrescenta o contato com as produções culturais, como as festividades.

Valene Smith (1992) classificou o turismo em cinco áreas, conforme a preferência dos turistas: étnica, cultural, histórica, ambiental e recreativa (sun, sea and sand). Para a autora, o turismo cultural abarca a "cor local", e está relacionado a modos de vida em processo de extinção, porém, que permanecem na memória humana por meio do patrimônio, como casas pitorescas, tecidos artesanais, automóveis, artesanato e trabalhos manuais.

É exatamente a cor local que diferencia o turismo cultural do turismo étnico, segundo van den Berghe e Keyes (1984), pois naquele há uma absorção mais difusa da "cor local", tendo uma ênfase nos objetos materiais, como a arquitetura, o vestuário, entre outros aspectos que vão além do modo de vida de um grupo étnico particular. Bahl (2003) também segue essa linha de pensamento e observa que os recursos principais desse tipo de turismo são aqueles provenientes de heranças patrimoniais de referencial cultural ou histórico, como monumentos, documentos e manifestações tradicionais.

Valene Smith (1992) apresenta uma divisão que distingue o turismo cultural do turismo histórico. Para a autora, o turismo histórico engloba os museus e as catedrais que fazem menção às glórias do passado, e as atividades mais frequentes costumam ser excursões com acompanhamento de um guia de turismo a monumentos e ruínas e 
espetáculos de luz e som. Para essa estudiosa, entre as atividades do turismo cultural, costuma-se incluir, por exemplo, a experimentação da gastronomia em pousadas rústicas, os espetáculos folclóricos, os festivais vinícolas e os rodeios, ou seja, nessa visão, trata-se de um turismo campesino, não tratando, nesse contexto, do turismo em espaço urbano.

Swarbrooke e Horner (2011) remetem ao turismo cultural atividades como visita a destinos ou atrativos que representam patrimônios; participação em festas tradicionais; férias motivadas pelo desejo de experimentar a culinária local, regional ou nacional; participação em atividades de lazer locais; visitação a locais de trabalho, como fazendas, centros de artesanato ou fábricas; e participação, na qualidade de plateia, em eventos esportivos tradicionais.

Já Santana Talavera (2003) engloba nesse tipo de turismo a participação em eventos locais, os encontros com populações exóticas e culturas distantes, a observação de monumentos, edifícios, povoados ou cidades que tenham como marca o legado de seu passado real ou hiper-real. Esse autor não separa o turismo cultural do turismo étnico; ao contrário, compreende o turismo cultural como uma denominação mais generalizada e abrangente do turismo étnico, ecoturismo, turismo rural, entre outros. Santana Talavera (2003) aponta ainda que o objetivo da viagem é a experimentação da cultura; o turismo cultural está relacionado com a atração que exerce 'o que as pessoas fazem', englobando a cultura popular, as artes e as galerias, a arquitetura, os eventos festivos, os museus e lugares históricos e patrimoniais.

Melanie Smith (2003) defende que há diferentes tipos de turismo cultural: o turismo patrimonial, o turismo das artes, o turismo criativo, o turismo urbano, o turismo rural, o turismo indígena e o turismo popular.

Faria (2008), cujo estudo faz parte do corpus de análise desta pesquisa, por sua vez, divide o segmento em turismo histórico, turismo gastronômico, turismo folclórico, etnoturismo (turismo cultural e étnico), turismo religioso, turismo esportivo, entre outros.

Já na visão de Graburn (1992), há o turismo cultural e o turismo de natureza (Figura 1) e estão inseridos no turismo cultural o turismo histórico e o turismo étnico, que, por sua vez, está inter-relacionado com o turismo de natureza.

Figura 1. Inter-relação dos tipos de turismo

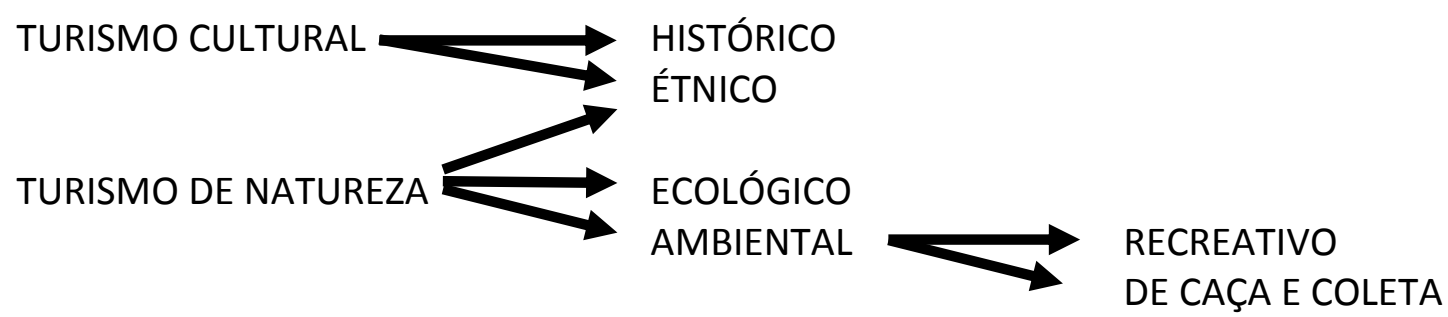

Adaptado de Graburn (1992, p. 61)

Apesar de o turismo cultural ser tratado como um segmento, Pereiro Pérez (2009) defende que, em um sentido genérico, o turismo pode ser entendido como uma prática cultural, uma expressão cultural; por isso, falar em turismo cultural seria reiteração. 


\section{O ETNOTURISMO OU TURISMO ÉTNICO}

Aqui entendido como sinônimo de turismo étnico, considera-se que o etnoturismo se insere em um sistema preexistente de relações étnicas entre um grupo dominante em um ou mais grupos marginalizados (van den Berghe, 1995). Os povos envolvidos com o turismo étnico tendem a ser, segundo Swain (1992), povos debilitados, seja pela história de exploração, seja pela carência de recursos, seja pelo poder insuficiente ou por não disporem dentro de seus territórios de grandes belezas naturais e, diante dessas condições, tais povos se veem obrigados a recriar sua etnicidade, bem como reivindicar seu território. Por isso, a natureza do turismo étnico, tal como o turismo ecológico, compreende um conceito territorial.

Esse segmento caracteriza-se pela atratividade que exercem as populações, oportunizando uma discussão antropológica, ecológica e sociológica (Lacerda, 2004).

Por vezes, esse segmento é entendido como parte do turismo cultural e utiliza a identidade e a cultura de determinado grupo étnico como atrativo turístico (Faria, 2005; 2008) ou, em outros casos apresentam-no como um segmento vinculado diretamente ao turismo cultural, sendo que o que os diferenciam são os traços de pertença e etnicidade dos grupos e comunidades onde ocorre o turismo étnico (Oliveira e Jesus, 2010).

Para Graburn (2009), o turismo étnico assenta-se na diferença e no exotismo das comunidades receptoras, e as mesmas forças contribuem para a autorrepresentação étnica regional e até nacional. Assim, a cultura "autêntica" é colocada na vitrine.

Na visão de Pereiro Pérez et al. (2012), o etnoturismo é uma denominação para o turismo étnico, turismo indígena, turismo aborígene, entre outros. Já para Faria (2005; 2008), esse segmento engloba o turismo indígena e o turismo étnico. Ademais, está vinculado a uma crença ocidental de que são os povos aborígenes os preservadores dos valores humanos mais autênticos e que eles mantêm um vínculo muito forte com a natureza e com o meio natural, relação esta já desgastada no ocidente (Pereiro Pérez et al., 2012).

Faria (2005; 2008) e Oliveira e Jesus (2010), entretanto, defendem que esse segmento não é desenvolvido prioritariamente pelos povos indígenas, pois é um equívoco relacionar o prefixo "etno" apenas a esses povos, esquecendo outras identidades. Exemplos disso, no Brasil, são os quilombolas, as comunidades que representam os processos de imigração europeia (como os italianos, alemães e pomeranos) e asiática (por exemplo os japoneses e chineses) e outros grupos que preservam seu legado histórico-cultural e o saberfazer tradicional (Oliveira e Jesus, 2010).

Assim como afirmado anteriormente, Graburn (1992) defende que o turismo étnico é uma combinação do turismo cultural e do turismo de natureza. Já para Santana Talavera (2003), o turismo étnico pode ser caracterizado como turismo alternativo, junto ao turismo ambiental e o ecoturismo, sendo que tais segmentos seriam alternativos ao turismo recreativo (V. Smith, 1992), mencionado anteriormente, ao qual Santana Talavera (2003) insere um quarto elemento, o sexo (sex).

Para van den Berghe e Keyes (1984), Valene Smith (1992) e Barretto (2005) o turismo étnico tem como atração principal o exotismo cultural de uma determinada população. Bahl (2009) defende que o turismo étnico pode ser entendido como um modo de expressão de 
interesse pela cultura e pelo modo de vida de outros povos, bem como uma tentativa de compreender as diferenças entre os povos.

São parte do atrativo os artefatos - arquitetura, vestuário, teatro, música, dança, entre outros - relacionados à busca do turista por experiências que não podem ser vivenciadas em seu local de residência habitual (van den Bergue e Keyes, 1984). Conforme esses autores, no turismo étnico, as comunidades receptoras não estão disponíveis simplesmente para atender aos turistas, como empregados na atividade turística, elas são o atrativo, um espetáculo vivo. Swain (1992) acrescenta o caráter mercantil do turismo étnico, uma vez que ele significa comercializar as atividades turísticas baseadas na vida típica da população; no turismo étnico, a cultura local tende a ser tratada como mercadoria sui generis (Greenwood, 1992; Harkin, 1995). Entre as atividades do turismo étnico, citam-se as visitas às casas e aldeias/comunidades indígenas, espetáculos de danças e cerimônias típicas, assim como a aquisição de souvenires e artesanato (Greenwood, 1992).

Para van den Berghe e Keyes (1984), esse tipo de turismo constitui um caso interessante no que tange às relações étnicas. Nesse sentido, há um esforço para fazer contato com uma realidade diferente, com a natureza não domesticada, com o passado alheio, com o comportamento de pessoas culturalmente distintas. Acima de tudo, há uma tentativa de que tal encontro seja uma experiência autêntica. Nesse sentido o turismo étnico pode ser praticado em lugares em que os grupos étnicos "sempre" estiveram presentes, como é o caso dos povos indígenas na América e tribos da África, ou em locais onde as etnias não são nativas, mas foram transplantadas, como é o caso de colônias de imigrantes (Barretto, 2005). A referida autora expõe que o debate em torno desse segmento leva a questionamentos no que tange aos direitos humanos e à ética, como, por exemplo, o limite do que pode ser transformado em algo turístico e se as comunidades devem inventar e reinventar tradições ou se seria uma melhor opção pesquisar sua história e considerar a memória coletiva.

Lac (2005) aborda que o fator principal no etnoturismo é a atração cultural ou a diferença estabelecida mediante a existência de uma fronteira étnica, que terá interpretações diferentes das atrações naturais no etnoturismo e no ecoturismo. Parte do exotismo procurado pelos turistas é inerente às fronteiras étnicas, uma vez que o turismo envolve contato com "nativos" por meio de uma barreira cultural. Entretanto, se o turista não busca o exotismo étnico, mas sim a contemplação da paisagem e dos monumentos, poderão ser fonte de irritação e ansiedade o exotismo, a fronteira étnica, bem como questões relativas à linguagem (van den Berghe; Keyes, 1984).

Assim como no turismo cultural, abordar o turismo étnico é uma reiteração, uma vez que, na medida em que o turista pertence a um grupo étnico distinto dos nativos da localidade que visita, e na medida em que os turistas e a comunidade receptora interagem, então o turismo é uma forma de relação necessariamente étnica, sendo essa essência duplamente verdadeira no turismo étnico ou etnoturismo (van den Berghe; Keyes, 1984; van den Berghe, 1995).

Essa mesma ideia é defendida por Grünewald (2002), que ressalta que o turismo étnico pode ser considerado a partir de duas perspectivas: o que é pedido ou desejado pelo turista, ou seja, o foco da viagem seria o nativo; o que o turista encontra/vê durante sua experiência no destino. Essa análise permite admitir-se que a visita a outra nação ou outro grupo étnico torna o turismo, em geral, étnico. Entretanto, o que define o segmento de 
turismo étnico é o movimento para a construção de uma etnia para exibição em uma arena turística.

\section{O TURISMO INDÍGENA E O TURISMO EM ÁREAS INDÍGENAS}

Ao abordar o turismo indígena e o, aqui denominado, turismo em áreas indígenas, faz-se necessário, primeiramente, abordar algumas questões referentes a esses povos. Baseando-se no "Estudo do problema de discriminação contra as populações indígenas" (Estudo Martínez Cobo) (Martínez Cobo, 1986), na Convenção 169 da Organização Internacional do Trabalho sobre os povos indígenas e tribais de 1989 (OIT, 1989) e no "Documento de Trabalho do Grupo de Trabalho sobre Populações Indígenas" (ONU, 1996), pode-se considerar, em âmbito global, que as populações indígenas são os povos tribais que descendem de populações que habitavam o território nacional ou a região geográfica na época da conquista ou colonização ou do estabelecimento das fronteiras estatais atuais; que representam grupos não dominantes da sociedade, que tiveram experiências de submissão, marginalização, expropriação, exclusão ou discriminação, independentemente de essas condições persistirem ou não; que sejam conscientes de sua identidade e que ela seja reconhecida por outros grupos ou por autoridades estatais, distinguindo-se da sociedade nacional por conta de suas condições sociais, culturais, econômicas e políticas, estando regidos total ou parcialmente por seus próprios costumes ou tradições ou por uma legislação especial, além de ter determinação de preservar, desenvolver e transmitir seus territórios ancestrais e sua identidade étnica para gerações futuras, contando com perpetuação voluntária da distinção cultural.

O antropólogo brasileiro Darcy Ribeiro compreendia os indígenas como a parcela da população que não se adaptava à sociedade em geral. Em princípio, não se concorda com tal afirmação, pois se acredita que a sociedade não indígena também deveria adaptar-se às culturas indígenas. No entanto, entende-se adequada a caracterização que esse autor faz do indígena como todo aquele que se reconhece como membro de uma comunidade précolombiana, motivado por costumes, hábitos e lealdade a uma tradição pré-colombiana (Ribeiro, 1957). Esclarece-se que, na presente pesquisa, adotou-se o termo "indígena" a partir dessa visão.

Outra discussão pertinente a este trabalho diz respeito ao termo 'turismo em terras indígenas', utilizado por diferentes autores. No caso do Brasil, grande parte dos indígenas vive em Terras Indígenas - Tls, uma determinada área delimitada pelo Estado, que são classificadas, com base no Estatuto do Índio (Brasil, 1973), na Constituição Federal de 1988 (Brasil, 1988) e no Decreto no 1.775, de 1996 (Brasil, 1996), em Terras Indígenas Tradicionalmente Ocupadas (direito originário dos povos indígenas), Reservas Indígenas (terras doadas por terceiros, adquiridas ou desapropriadas pela União, para posse permanente dos povos indígenas), Terras Dominiais (propriedade das comunidades indígenas oriundas de qualquer forma de aquisição) e Interditadas (áreas interditadas pela Fundação Nacional do Índio - Funai - para proteção dos povos e grupos indígenas isolados). No entanto, considera-se mais adequado utilizar o termo 'turismo em áreas/territórios indígenas', uma vez que nem todas as comunidades indígenas estão inseridas em alguma TI.

No que tange à conceituação dos termos, o denominado turismo indígena se caracteriza pelo modo de fazer e desenvolver o turismo - em geral comunitário, participativo, sustentável, distributivo e ecológico; pelas motivações e experiências dos 
turistas - atratividades indígenas e interculturalidade; pelo local onde se desenvolve habitat indígena/ecologicamente preservados; e por sua diferença identitária para adaptarse a um contexto global com o qual se relaciona - diferencial indígena (Pereiro Pérez, 2014), assim, o turismo indígena inclui ofertas preparadas pelos próprios nativos, com base na temática indígena (Hinch e Butler, 1996).

Esse turismo está associado ao turismo étnico, pois assim como aborda Bahl (2009) o turismo étnico se forma a partir dos resultados de dois tipos de sentimento: o primeiro está associado ao aparato social e à cultura de uma determinada localidade com sua identidade e diferenciação; o segundo está ligado à ideia de divulgação da existência de um grupo ou etnia, visando a seu reconhecimento e a sua inserção em um contexto nacional ou internacional. No entanto, o turismo indígena teria uma singularidade em relação ao turismo étnico como um todo: os quatro Hs, definidos por Valene Smith (1996) para definir o turismo indígena, sendo eles: o assentamento geográfico (habitat), as tradições etnográficas (herança cultural), os efeitos da aculturação (história) o artesanato (handcraft, em inglês) comercializável.

Na visão de Morales González (2008), o turismo indígena compreende as atividades onde as comunidades indígenas oferecem ao visitante a oportunidade de compartilhar suas tradições e seus costumes. Esse compartilhamento de experiências contribui para a valorização e para a preservação dos elementos culturais dessas comunidades, além do reconhecimento de sua identidade. Esse autor se baseia no turismo indígena do México, país em que o turismo indígena é pautado no desenvolvimento de microempresas sociais que buscam o resgate das tradições e da identidade das comunidades e, consequentemente, a revalorização e reapropriação da cultura e do território (Morales González, 2008). Hinch e Butler (1996) também abordam as empresas, ao defenderem que o turismo indígena é o turismo no qual os próprios indígenas participam da atividade com empresas próprias ou por meio da comercialização da cultura, considerando seu aspecto eminentemente turístico e a demanda.

Esse é o mesmo posicionamento de Swain (1992); Hinch (2004) e Zeppel (2006) que defendem que o turismo indígena é o tipo de turismo que tem suas bases na terra e identidade cultural de um grupo indígena e que é controlado por ele. Segundo Hinch (2004) há um constante aumento da demanda por esse tipo de turista porque a sociedade tornouse mais complexa e agitada e, por isso, os turistas têm procurado lugares que são alternativos a esse modo de vida e vários povos indígenas estão atendendo a essa demanda, como parte de sua estratégia para a própria sobrevivência cultural. Nesse sentido, para as comunidades indígenas, o turismo é uma demonstração de que seus povos são valorizados por suas culturas e patrimônio, únicos em relação ao mundo exterior (Bunten, 2014). Por isso, segundo esse autor, através de um planejamento cuidadoso, o turismo pode ser um meio para as comunidades indígenas assumirem o controle do poder.

Faria (2008), por sua vez, defende que esse turismo pode ser desenvolvido nos limites das TIs (aqui, leia-se áreas indígenas) ou fora delas, desde que a identidade cultural do local seja a indígena e o controle da gestão esteja com as comunidades ou povos indígenas. Para Oliveira (2006), o turismo indígena é um turismo emissivo, ou seja, é o turismo realizado pelos próprios indígenas, e o turismo em territórios indígenas é um turismo receptivo, no qual turistas visitam territórios pertencentes a um grupo ou a uma comunidade indígena. Essa investigadora cita que 
[...] o turismo indígena pode ser compreendido como um novo segmento turístico que está sendo organizado pelas associações e populações indígenas, o que contribui para que os turistas possam ser interpretados no contexto da reterritorialização nas arenas turísticas (Oliveira, 2006, p. 100).

Apesar dessa concepção, alguns indígenas não se sentem turistas, como é o caso dos Pataxó, assim como relatado por Grünewald (1999), em um dos estudos analisados: embora façam passeios como turistas e as sensações da experiência são sentidas por eles também, as viagens realizadas por eles não têm cunho recreativo; portanto, preferem dizer que são passeios, não turismo.

O desenvolvimento desse tipo de turismo está ocorrendo de forma mais acentuada em países ditos desenvolvidos, como é o caso da Austrália e Nova Zelândia, onde a relação entre a sociedade dominante e os povos indígenas é complexa e tensa, mas notadamente enriquecedora, especialmente e tanto os aborígenes australianos quanto os Maori têm reconhecido que o turismo e a plataforma de defesa que ele fornece é importante na obtenção de reconhecimento tanto para a manutenção de suas culturas quanto para a reivindicação de seus direitos (Ryan, 2005).

Em relação ao turismo em áreas indígenas, este é por vezes associado ao ecoturismo. Chaves (2012), no entanto, defende que o turismo nessas áreas extrapola o conceito de ecoturismo, uma vez que o interesse turístico, o atrativo em questão, são os próprios indígenas, bem como sua organização social, seus costumes, suas tradições e suas crenças, e não o ambiente natural local.

Guimarães (2006) ressalta também que, mesmo que se escolha denominar de ecoturismo o turismo em áreas indígenas, essa designação carrega preconceitos, posicionando os indígenas como seres animalescos. Para o autor, outros conceitos parecem mais apropriados para referenciar o turismo em áreas indígenas, como a expressão 'turismo étnico'. Nesse sentido, cabe também abordar outras concepções sobre o turismo em áreas indígenas.

\section{ECOTURISMO E OUTRAS CONCEPÇÕES}

Conforme mencionado, alguns autores relacionam o turismo em áreas indígenas com o ecoturismo. Para Faria (2005; 2008), esse segmento é uma convergência do turismo de natureza com o turismo cultural e tem um caráter comunitário pautado no planejamento participativo.

López Pardo e Palomino Villavicencio (2008) destacam o caso do México, onde o ecoturismo representa, para as comunidades indígenas, uma oportunidade para melhorar suas condições de vida e aspirar ao desenvolvimento. Conforme esses pesquisadores, o ecoturismo não apenas valoriza seus territorios, mas também permite sua reapropriação e reuso dos recursos naturais para sua existência - dos que não foram privados ao serem decretados vários de seus territorios áreas naturais protegidas (60\% da população indígena mexicana se assenta em zonas de conservação) e modificar sua tradicional desvantagem com o mercado nacional. 
Ainda sobre o México, Palomino Villavicencio e López Pardo (2011) destacam que há pelo menos 600 empresas e projetos sociais que envolvem a centenas de campesinos, ejidatários e indígenas que oferecem seus serviços e atividades ecoturísticas ou de turismo alternativo, sendo assim, entende-se que, nesse caso, o termo ecoturismo seria o mais adequado para o turismo realizado em áreas indígenas que tenham seu ambiente natural preservado.

O ecoturismo não deve ser confundido com o turismo ecológico ou com quaisquer atividades turísticas que sejam pautadas no patrimônio natural como atrativo principal, pois aquele é uma junção do ambiente natural e motivações culturais (Faria 2005; 2008). Verificase que o ecoturismo tem relação estreita com o turismo em áreas indígenas, uma vez que também acaba por agregar atrativos culturais, é realizado em áreas naturais, envolvendo a comunidade local, e deve se basear na sustentabilidade, segundo Brandão (2012). Nessa perspectiva, Zeppel (2006) aponta que o ecoturismo inclui as comunidades indígenas por sua forte relação com o ambiente natural, incluindo vínculos naturais, culturais, espirituais e físicos entre os povos indígenas e seus territórios tradicionais. Segundo esse autor, esse tipo de turismo pode se denominar turismo cultural indígena ou turismo ecocultural.

No entanto, assim como sinalizado por Chaves (2012), é preciso levar em consideração que o conceito de turismo em áreas indígenas extrapola o conceito de ecoturismo, ainda que seja um segmento expressivo. Nesse sentido, Faria (2008) cunha um termo que avalia ser o mais próximo do ideal para os territórios indígenas: o 'ecoturismo indígena', que seria:

[...] o ecoturismo promovido dentro dos limites das terras indígenas através do planejamento/gestão participativa e comunitária, respeitando os valores sociais, culturais e ambientais dos diferentes povos envolvidos em que a comunidade é a principal beneficiada (Faria, 2008, p. 47).

Ainda que o ecoturismo não seja o único segmento desenvolvido em áreas indígenas, Baggio (2007), em um dos estudos analisados, ressalta o potencial dessas áreas. Para esse pesquisador, as Tls podem ser os espaços que apresentam maior potencial para 0 desenvolvimento do ecoturismo, uma vez que conservam as boas condições de seu patrimônio ambiental e cultural.

Faz-se necessário, outrossim, distinguir o turismo étnico do ecoturismo. Assim como destacado por Lac (2005), apesar de não ser simples diferenciar esses dois tipos de turismo, entende-se que, no turismo étnico, a atração principal é a fronteira étnica, enquanto no ecoturismo, ainda que a cultura seja importante, há uma preocupação maior com o ambiente natural. No entanto, essa pesquisadora ressalta que ambos os segmentos podem ser entendidos como parte do turismo alternativo, que surgiu na década de 1970 em contraposição ao turismo de massa.

O ecoturismo apresenta pelo menos uma característica representativa do turismo de base comunitária: a plena participação da comunidade (Brandão, 2012). Esse é outro conceito comumente aliado ao turismo em áreas indígenas, conforme pode ser percebido no levantamento bibliográfico feito para esta pesquisa e nos estudos aqui analisados. 
Sampaio, Fernandes e Philippi Jr. (2010) abordam que, para definir o turismo de base comunitária, parte-se do princípio de que ainda há alguns modos de vida não urbanos que podem sinalizar aprendizados a respeito da sustentabilidade do desenvolvimento humano, mesmo que essas comunidades representem, para o senso comum, modos de vida obsoletos e que contem com uma desvantagem histórica. Entre essas comunidades, os autores assinalam como exemplos, no Brasil, as comunidades extrativistas, pesqueiras, ribeirinhas, faxinalenses, quilombolas, caiçaras e as indígenas, entre várias outras.

No que tange à dimensão conceitual, cabe destacar que o turismo de base comunitária tem como motivação a superação da lógica capitalista utilitarista materialista tendo por base os princípios de equidade social, prudência ecológica e responsabilidade econômica (Fortunato; Silva, 2013), ou seja, ele não representa um segmento do turismo, mas sim uma alternativa ao turismo de massa. Ademais, assim como destacado por Araújo e Gelbcke (2008), comumente se relacionam todos os projetos turísticos envolvendo comunidades tradicionais com o turismo comunitário, o que não é adequado.

O turismo de base comunitária pode ser considerado um instrumento para inclusão social e promoção do desenvolvimento sustentável, com plena participação da população no processo de construção, planejamento e organização da atividade turística (Brandão, 2012). Conjuntamente, relaciona-se o turismo em territórios indígenas ao desenvolvimento de base local, uma vez que o modelo ideal de turismo nesses territórios seria o gerido pelos próprios indígenas, assim como apontado por Oliveira (2006) em uma das pesquisas analisadas. No entanto, essa nem sempre é a realidade. Um dos estudos do corpus de análise (Jesus, 2012) aborda que, com ressalvas, o turismo de base local promove aprendizado, conhecimento, encontro entre pessoas e consequente intercâmbio cultural, e esses preceitos, na visão desse pesquisador, se encaixam nos valores tratados pelo turismo indígena.

Thomson-Carr (2013), por sua vez, destaca o turismo ecocultural ao abordar o turismo praticado em territórios Maori desde a década de 1970, na Nova Zelândia, o qual provocou uma intensa revitalização do orgulho indígena. Essa autora usa o termo 'ecocultural' por haver uma interpretação de valores culturais em contextos naturais.

Assim, pode-se perceber que há diversas designações para o turismo em áreas indígenas, e este está, por vezes, relacionado a um tipo de turismo que seja aliado ao interesse pelo ambiente natural, como o ecoturismo, e que seja pautado nas premissas da sustentabilidade, com desenvolvimento turístico baseado em sua gestão pelas comunidades receptoras.

\section{O TURISMO EM ÁREAS INDÍGENAS NO BRASIL NA VISÃO DOS PESQUISADORES}

Após a revisão de literatura, buscou-se averiguar como os pesquisadores brasileiros entendiam o turismo que vinha ocorrendo nas comunidades indígenas onde desenvolveram suas pesquisas (teses ou dissertações). Constatou-se, na análise das teses e dissertações disponibilizadas (CAPES, 2015), o uso de diversas nomenclaturas, entre segmentos, conceitos e modos de gestão do turismo. A seguir, apresenta-se um quadro identificando resumidamente o tipo de gestão turística ou segmento turístico desenvolvido nas comunidades estudadas, conforme percebido ou averiguado pelos pesquisadores. 
Quadro 1. Nomenclaturas utilizadas pelos pesquisadores

\begin{tabular}{|c|c|c|}
\hline AUTOR(A) & LOCAL & NOMENCLATURA \\
\hline \multirow[t]{2}{*}{$\begin{array}{l}\text { Grünewald } \\
\text { (1999) }\end{array}$} & $\begin{array}{l}\text { TI Coroa } \\
\text { Vermelha }\end{array}$ & $\begin{array}{l}\text { - O movimento de turista não indicava a intenção de ver a cultura } \\
\text { Pataxó, não havia o objetivo turístico de visitação das aldeias; } \\
\text { - Era desenvolvido o turismo histórico e o cultural; } \\
\text { - Começava a ganhar forma a ideia de um turismo étnico; } \\
\text { - A liderança desejava implantar o ecoturismo. }\end{array}$ \\
\hline & $\begin{array}{l}\text { Aldeia Barra } \\
\text { Velha }\end{array}$ & $\begin{array}{l}\text { - Os turistas vão à aldeia conhecer o modo de vida dos indígenas em seu } \\
\text { lugar de "nativo". Assim, desde a perspectiva do autor, o turismo que } \\
\text { incidia sobre Barra Velha é o étnico; } \\
\text { - Não havia, no entanto, o desenvolvimento de um turismo sustentável. }\end{array}$ \\
\hline $\begin{array}{l}\text { Lacerda } \\
(2004)\end{array}$ & $\begin{array}{l}\text { Bairro/Aldeia } \\
\text { Marçal de } \\
\text { Souza }\end{array}$ & $\begin{array}{l}\text { - Possibilidade para o turismo científico; } \\
\text { - O etnoturismo era uma utopia ainda, pois mesmo o turismo } \\
\text { "tradicional" ainda não havia sido implementado; } \\
\text { - O turismo étnico/etnoturismo, ecoturismo e outras denominações } \\
\text { correspondentes pouco acontecem quando as visitações se transformam } \\
\text { apenas em momentos de observação e compra de artesanato e relatos } \\
\text { da história do local, sem nenhuma integração com a comunidade, tal } \\
\text { como mencionou ocorrer no bairro Marçal de Souza. }\end{array}$ \\
\hline $\begin{array}{l}\text { Lac } \\
(2005)\end{array}$ & TI de Iraí & $\begin{array}{l}\text { - Apesar de não deixar claro que o que ocorre na TI de Iraí seria o } \\
\text { turismo étnico/etnoturismo, pode-se afirmar que a autora se posiciona } \\
\text { favorável a esse segmento, uma vez que o aborda várias vezes no } \\
\text { decorrer da pesquisa. }\end{array}$ \\
\hline \multirow[t]{2}{*}{ Nunes (2006) } & $\begin{array}{l}\text { Aldeia Puiwa } \\
\text { Poho }\end{array}$ & $\begin{array}{l}\text { - O principal motivo que atraia turistas era a busca pelo estereótipo de } \\
\text { "índio intacto", o que seria uma característica do turismo étnico; } \\
\text { - Era comercializado como ecoturismo, e foi concebido como um projeto } \\
\text { de turismo sustentável. }\end{array}$ \\
\hline & RI de Dourados & - Menciona apenas ter se tratado de turismo em território indígena. \\
\hline Oliveira (2006) & Território Krahô & $\begin{array}{l}\text { - Aborda apenas o turismo em territórios indígenas, no qual podem estar } \\
\text { inseridos o turismo étnico e ecoturismo (no caso dos Krahô estavam } \\
\text { sendo desenvolvidos ambos); } \\
\text { - Destaca o turismo realizado pelos próprios indígenas, um novo } \\
\text { conceito para turismo indígena. }\end{array}$ \\
\hline Baggio (2007) & $\begin{array}{l}\text { TI } \\
\text { Mangueirinha }\end{array}$ & $\begin{array}{l}\text { - O segmento desenvolvido na TI Mangueirinha é o ecoturismo, mais } \\
\text { propriamente dito o ecoturismo indígena, em que os visitantes } \\
\text { experienciavam o ambiente cultural e natural das populações indígenas. }\end{array}$ \\
\hline $\begin{array}{l}\text { Faria } \\
(2008)\end{array}$ & $\begin{array}{l}\text { São Gabriel da } \\
\text { Cachoeira }\end{array}$ & $\begin{array}{l}\text { - Ecoturismo indígena é o segmento que melhor se adequa aos } \\
\text { territórios indígenas é o ecoturismo; } \\
\text { - O ecoturismo indígena seria, para a autora, desenvolvido sobre as } \\
\text { premissas do planejamento e gestão comunitária, por isso, seria de base } \\
\text { comunitária; } \\
\text { - Em São Gabriel da Cachoeira, ocorria um turismo "clandestino", sem } \\
\text { planejamento, e, por isso, não considerava a prática como ecoturismo } \\
\text { ou turismo ecológico, mas sim, no máximo, como um turismo de } \\
\text { natureza (que em sua visão é quando a principal motivação da atividade } \\
\text { é o ambiente natural). }\end{array}$ \\
\hline Ramos (2008) & Olivença, Ilhéus & $\begin{array}{l}\text { - Olivença era um local procurado por conta de suas águas medicinais, } \\
\text { por tanto, pode-se inferir que ocorreu o turismo de saúde, que, } \\
\text { intensificou-se o fluxo de visitantes atraídos pelas praias, portanto, um } \\
\text { turismo de sol e praia; } \\
\text { - Não há menção ao turismo indígena no local. }\end{array}$ \\
\hline Santos (2010) & $\begin{array}{l}\text { Aldeia Sahu- } \\
\text { Apé }\end{array}$ & $\begin{array}{l}\text { - Aborda o turismo em terras e comunidades indígenas; } \\
\text { - A autora menciona que os povos indígenas integram o turismo cultural, } \\
\text { o ecoturismo e o turismo de pesca; } \\
\text { - Os Sateré-Mawé, a Associação Indígena Sahu-Apé tinha, entre os }\end{array}$ \\
\hline
\end{tabular}




\begin{tabular}{|c|c|c|}
\hline & & trabalhos mais relevantes, a organização da atividade de etnoturismo. \\
\hline $\begin{array}{l}\text { Leandro } \\
\text { (2011) }\end{array}$ & $\begin{array}{l}\text { TI Sete de } \\
\text { Setembro }\end{array}$ & $\begin{array}{l}\text { - Ecoturismo indígena é o segmento que melhor se adequa; } \\
\text { - Na gestão territorial da TI, considerava-se como segmento a ser } \\
\text { desenvolvido o ecoturismo, como parte do turismo de base comunitária. }\end{array}$ \\
\hline \multirow[t]{2}{*}{ Lustosa (2012) } & $\begin{array}{l}\text { TI Aldeia Lagoa } \\
\text { Encantada }\end{array}$ & $\begin{array}{l}\text { - Estava sendo desenvolvido o turismo comunitário, contrapondo o } \\
\text { turismo global, voltado para os megaempreendimentos. }\end{array}$ \\
\hline & $\begin{array}{l}\text { TI Tremembé } \\
\text { São José e } \\
\text { Buriti }\end{array}$ & $\begin{array}{l}\text { - A comunidade desejava desenvolver um turismo que coincidisse com } \\
\text { as premissas do turismo comunitário, para contrapor a ameaça oriunda } \\
\text { de um megaprojeto. }\end{array}$ \\
\hline $\begin{array}{l}\text { Neves } \\
2012)\end{array}$ & $\begin{array}{l}\text { TI da Coroa } \\
\text { Vermelha }\end{array}$ & $\begin{array}{l}\text { - O autor aborda que era desenvolvido o turismo indígena, sem entrar } \\
\text { em pormenores; } \\
\text { - Havia uma iniciativa de ecoturismo ocorrendo na Reserva da Jaqueira; } \\
\text { - Não foi possível saber se, na opinião do pesquisador, o ecoturismo } \\
\text { seria parte desse turismo indígena ou se não coincidiam. }\end{array}$ \\
\hline \multirow[t]{2}{*}{$\begin{array}{l}\text { Jesus } \\
(2012)\end{array}$} & $\begin{array}{l}\text { Maori, Ilha } \\
\text { Norte da Nova } \\
\text { Zelândia }\end{array}$ & $\begin{array}{l}\text { - Não há uma especificação do que ocorria, na visão desse autor, nas } \\
\text { comunidades da Nova Zelândia, porém, conforme pode ser constatado } \\
\text { em sua tese, há uma inclinação para o turismo indígena, que fomenta } \\
\text { ações de base comunitária. }\end{array}$ \\
\hline & RI Kadiwéu & $\begin{array}{l}\text { - Não desenvolviam nenhum tipo de atividade turística; porém, o autor } \\
\text { utilizou os exemplos das comunidades da Nova Zelândia como possíveis } \\
\text { práticas na RI Kadiwéu. }\end{array}$ \\
\hline $\begin{array}{l}\text { Brandão } \\
(2012)\end{array}$ & TI São Marcos & $\begin{array}{l}\text { - Segundo a pesquisa, é possível compreender que a autora indica que o } \\
\text { turismo indígena era desenvolvido na TI, seguindo as premissas do } \\
\text { turismo sustentável e de base comunitária; }\end{array}$ \\
\hline
\end{tabular}

Elaboração própria (2015)

Pode-se perceber, com a síntese apresentada no quadro acima, que cada pesquisador teve uma perspectiva quanto ao turismo que estava sendo desenvolvido ou planejado nas comunidades indígenas onde realizaram suas pesquisas. Percebe-se, no entanto, uma inclinação para o uso dos termos 'turismo étnico' e 'turismo indígena', esse último utilizado de modo genérico, sem uma explicação sobre o que realmente significa a nomenclatura.

Cabe salientar que não foi o intuito dessa análise questionar os conceitos apontados pelos pesquisadores, mas sim identificar como esses autores caracterizaram o turismo nas comunidades estudadas. Por essa razão, preferiu-se fazer uma separação dos termos, explicando como a presente pesquisa incorporou cada nomenclatura dos tipos de turismo. Essa proposta segue abaixo.

\section{PROPOSTA DE DIVISÃO DOS TIPOS DE TURISMO}

Após a análise bibliográfica exposta anteriormente, abarcando autores nacionais e estrangeiros que apresentam os conceitos de turismo cultural, turismo étnico, turismo indígena, turismo em áreas indígenas e outras denominações, ressalta-se a importância de apresentar um modelo de divisão dos conceitos a partir dos segmentos e dos tipos de gestão do turismo, conforme a especificidade de cada elemento, levando em conta as suas interrelações. Por isso foi criado um modelo explicativo de como os autores desse artigo entendem que o turismo envolvendo comunidades indígenas - e as diversas nomenclaturas utilizadas - pode ser dividido. 
O modelo segue abaixo (Figura 3) e é explicado em seguida.

Figura 1. Divisão dos tipos de turismo conforme conceituação

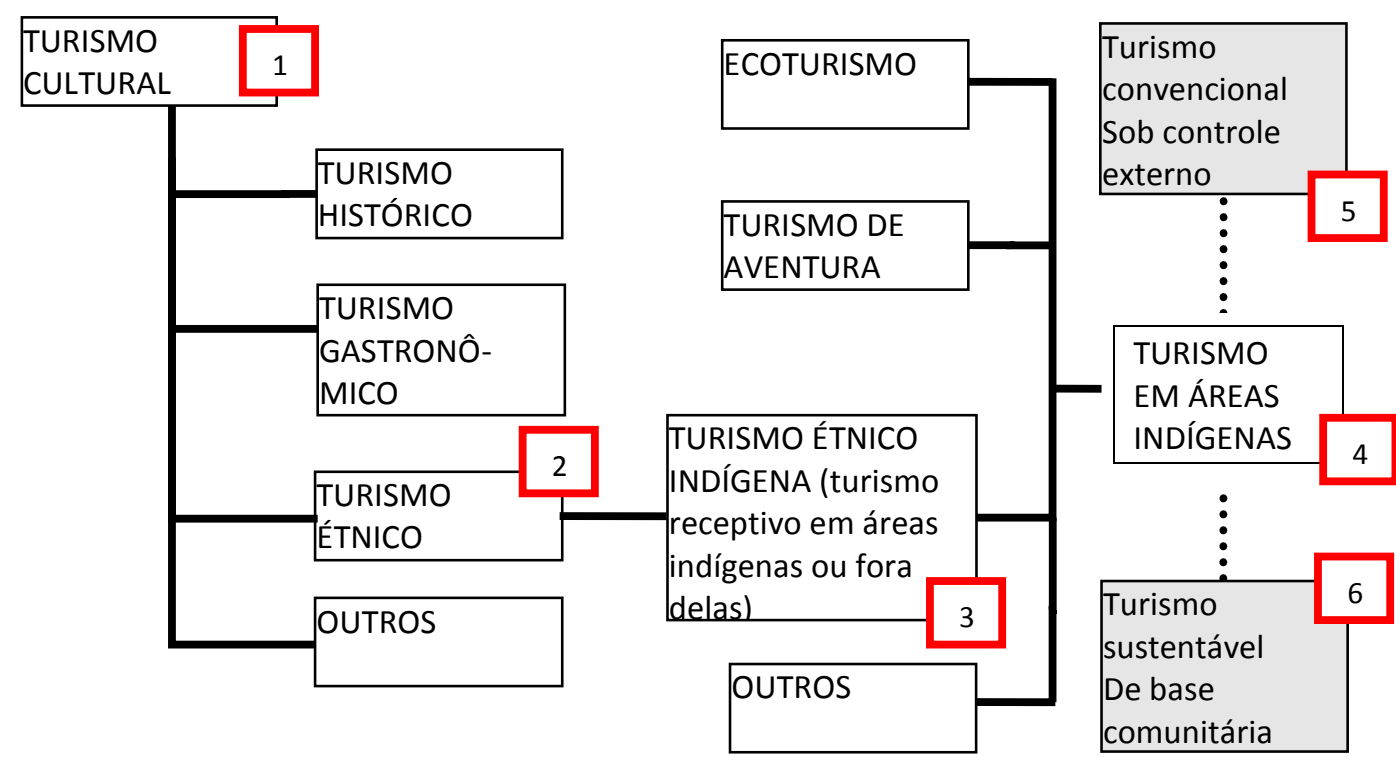

Elaboração própria (2014)

Na figura acima se representa uma separação dos tipos de turismo conforme análise das conceituações e caracterizações dos autores anteriormente apresentados. A partir dela, levou-se em consideração o seguinte:

1) Turismo cultural: o turismo cultural representa um segmento composto por uma gama de "subsegmentos", como o turismo gastronômico, o turismo arqueológico, o dark tourism, o turismo histórico, o turismo arquitetônico e o turismo étnico, apenas para exemplificar. Concorda-se com a perspectiva de Costa (2009), Faria (2008), van den Berghe e Keyes (1984) e Bahl (2003) de abordar o turismo cultural relacionado a experiências junto ao patrimônio cultural material ou imaterial. Também se concorda com Valene Smith (1992), que defende que o turismo cultural diz respeito a culturas extintas ou em vias de extinção, mas que se perpetuaram nos patrimônios, como arquitetura e vestimentas. O turismo cultural se relaciona com o turismo étnico, uma vez que se entende serem o modo de vida de uma comunidade e seu exotismo pautados em diversos aspectos da cultura de um local, e, por vezes, esses aspectos incluem a arquitetura, o artesanato e as artes, as vestimentas, a gastronomia e os festivais tradicionais.

2) Turismo étnico: inserido no turismo cultural, o etnoturismo ou turismo étnico sobrepõe-se em um sistema preexistente de relações étnicas entre um grupo dominante e um ou mais grupos marginalizados cujo atrativo turístico é o exotismo de determinado grupo étnico, como, no caso do Brasil, os quilombolas, as comunidades que representam os processos de imigração europeia e asiática e outros grupos que preservam seu legado histórico-cultural e o saber-fazer 
tradicional (Oliveira; Jesus, 2010; van den Berghe, 1995; Faria, 2005; 2008; van den Berghe; Keyes, 1984; Valene Smith, 1992; Barretto, 2005).

3) Turismo étnico indígena: a denominação 'turismo étnico indígena' diz respeito ao turismo étnico desenvolvido em áreas indígenas ou fora delas, desde que a identidade focal seja a indígena e a atividade turística seja gerida por um grupo ou por uma comunidade indígena, assim como destacado por Faria (2008). Tendo em vista que se defende que o turismo indígena é o turismo emissivo, considerou-se necessário estabelecer uma diferenciação entre os termos. Esse turismo, por sua vez, diferencia-se do turismo em áreas indígenas.

4) Turismo em áreas indígenas: o turismo em áreas indígenas é visto aqui como qualquer turismo que ocorra dentro de uma área pertencente a grupo(s) indígena(s). Nesse sentido, concorda-se com Chaves (2012) e Guimarães (2006), que destacam que o turismo em áreas indígenas extrapola o conceito de ecoturismo. Na maioria das vezes, as comunidades indígenas estão inseridas em áreas naturais, como, por exemplo, no Parque Nacional do Pico da Neblina, no Amazonas (Faria, 2005), e, por isso, é aliado ao ecoturismo. Entretanto, destacase que o conceito de turismo em áreas indígenas tem relação com um fator territorial; porém, o turista pode estar buscando outro tipo de turismo, como o turismo científico (realizado por cientistas e pesquisadores), o turismo de aventura, o turismo de saúde (medicina tradicional), o turismo cultural em sua essência e o próprio turismo étnico indígena.

5) Turismo de base comunitária/sustentável: tanto o turismo étnico indígena quanto o turismo em áreas indígenas podem ser desenvolvidos sob a ótica da sustentabilidade e pela própria comunidade, sendo assim caracterizados como um turismo tido como sustentável e como turismo de base comunitária. No entanto, há casos em que se desenvolve o turismo convencional, controlado por agentes externos, sem a participação das comunidades no processo de planejamento, gestão e controle da atividade.

À parte desses segmentos, tem-se o turismo indígena, que representa o turismo emissivo realizado pelos indígenas, tal como defendido por Oliveira (2006). Esse turismo pode envolver qualquer segmento; como exemplo, tem-se o turismo de negócios, para venda de artesanato, o turismo de lazer, com visita a outras comunidades, o turismo de eventos, com participação em congressos, feiras, mostras, entre outros.

Assim exposto, a partir da conceituação e da caracterização dos segmentos e tipos de gestão do turismo por diversos pesquisadores, criou-se a presente proposta de divisão e delimitação desses conceitos, com suas referidas inter-relações. Cabe destacar que, com essa proposta, pretendeu-se instigar a discussão e contribuir para a construção de uma teoria para o turismo, considerando a importância de se delinear claramente os conceitos dentro dessa teoria. 


\section{CONSIDERAÇÕES FINAIS}

Influenciado pelo modelo fordista de produção e consumo, o turismo se tornou massivo e os destinos turísticos se tornaram homogêneos, com ínfimas diferenciações, alta concentração de visitantes, com um perfil padrão, em uma mesma localidade, principalmente em localidades onde é possível praticar o denominado turismo de sol e praia (Torres, 2002). No entanto, foi possível compreender que, com o surgimento de outro modelo na década de 1970, o Pós-Fordismo, ocorreu uma movimentação do turismo de massa para uma atividade turística mais branda e diversificada, por conta de uma alteração nas preferências da demanda (Molina, 2003), surgindo assim vários novos segmentos (Pereiro Pérez et al., 2012; Torres, 2002; Santana Talavera, 2003). Dentre esses segmentos encontra-se o turismo cultural, o turismo étnico e o turismo indígena.

Com a presente pesquisa compreendeu-se que a conceituação e divisão dos segmentos e tipos de turismo são importantes não apenas para a construção de teorias inerentes ao turismo, mas para que seja possível entender as diferenças, as similaridades e como os segmentos se inter-relacionam.

A caracterização e conceituação dos tipos de turismo variam conforme a visão de cada autor. Pode-se perceber que há uma ampla variedade de conceitos, geralmente distintos. Para alguns autores, como Valene Smith (1992) e van den Berghe e Keyes (1984), o turismo cultural é um segmento diferente do turismo étnico. Já na visão de outros estudiosos como Santana Talavera (2003), Melanie Smith (2003), Graburn (1992) e Faria (2005; 2008) o turismo cultural é um segmento mais amplo que abarca, dentre outros, o turismo étnico. Nesse sentido também há quem defenda que o turismo étnico é uma mescla do turismo cultural com o turismo de natureza.

No que tange ao etnoturismo, alguns pesquisadores como Pereiro Pérez et al. (2012) e Faria $(2005 ; 2008)$ abordam que esse termo abarca o turismo étnico e o turismo indígena e aborígene. Já Santana Talavera (2003) defende que o turismo étnico é um turismo alternativo ao turismo de massa, assim como o turismo ambiental e o ecoturismo. Também, alguns estudiosos abordam a relação entre ecoturismo e etnoturismo. Nesse sentido alguns acreditam que são diferentes interpretações de uma fronteira étnica (Lac, 2004), outros ressaltam que o turismo em áreas indígenas é associado por vezes ao ecoturismo, porém essa designação é neutra e não abarca a realidade em sua totalidade (Chaves, 2012; Guimarães, 2006).

Entende-se que não há uma definição universal do que é cada tipo de turismo e nem há necessidade de tal homogeneização, no entanto, acredita-se que os pesquisadores, órgãos governamentais e até mesmo as comunidades indígenas precisam definir os conceitos para si próprios a fim de otimizar sua utilização, ter clareza do que significa cada tipo de turismo e qual deles será base de seu discurso, planejamento e ações.

Outro aspecto importante a ser destacado é o fato de que diversos autores, como Valene Smith (1992); Melanie Smith (2003) e Pereiro Pérez et al. (2012) utilizam a expressão turismo indígena generalizando o turismo envolvendo comunidades pertencentes a determinado território antes de sua colonização, sem fazer diferenciação entre indígenas e aborígenes. Entende-se que não é um problema que, em suas pesquisas, os estudiosos não aprofundem o debate a respeito da conceituação, com exceção às pesquisas que tenham o foco nessas discussões teóricas. No entanto, sendo o turismo um campo de pesquisa 
relativamente pouco explorado, em comparação a outros, questiona-se a importância de se discutir, definir e refletir a respeito das inúmeras nomenclaturas utilizadas, que por vezes se inter-relacionam ou se confundem, como é o caso do turismo envolvendo comunidades indígenas. No entanto, há que se considerar, nesse debate, as peculiaridades das comunidades indígenas e de seus habitats, que são indispensáveis para a definição do turismo a ser desenvolvido (como, por exemplo, se a comunidade é urbana ou está estabelecida em uma floresta).

Por fim, destaca-se o fato de que não há uma diferenciação entre o turismo realizado por indígenas (emissivo) do turismo recebido pelos indígenas (receptivo), por isso faz-se necessário refletir sobre o termo turismo indígena. Embora a visão eurocentrista defina o turismo enquanto uma atividade praticada pelos "ocidentais", é preciso considerar e inclusive aprofundar as investigações a respeito das viagens realizadas pelos próprios indígenas, sejam elas parte da prática do lazer ou não.

Compreende-se com a presente pesquisa que, os estudos sobre o turismo estão em constante evolução e que os investigadores adotam correntes de pensamento que acreditam ser pertinentes. Inserida nessa questão está a conceituação não apenas do que é o turismo e o turista, mas também o que caracteriza cada segmento dessa atividade. Desse modo o presente artigo teve como objetivo explorar as especificidades dos segmentos abordados e apresentar uma reflexão sobre os conceitos e as relações entre os segmentos, através da análise bibliográfica. Apresentou-se um esquema com uma proposta de divisão dos segmentos e tipos de turismo que permeiam o debate sobre a relação entre turismo e comunidades indígenas. Buscou-se com isso promover uma reflexão e instigar o debate acadêmico sobre conceituações inerentes ao turismo, contribuindo assim para o desenvolvimento da sua teorização e para a compreensão do fenômeno e da atividade turística como um todo.

\section{REFERÊNCIAS}

Araújo, G. P. de; Gelbcke, D. L. (2008). Turismo comunitário: uma perspectiva ética e educativa de desenvolvimento. Turismo Visão e Ação, 10(3), 358-377. Disponível em: <http://www6.univali.br/seer/index.php/rtva/article/view/770/625>. Consultado em: 01/04/2016.

Baggio, A. J. (2007). Ecoturismo: alternativa sustentável de valorização do patrimônio natural e cultural da Terra Indígena Mangueirinha, PR. (Dissertação de Mestrado em Ciências Sociais Aplicadas). Universidade Estadual de Ponta Grossa. Ponta Grossa, Brasil. Disponível em:

<http://www.dominiopublico.gov.br/download/texto/cp043493.pdf>. Consultado em: 04/03/2016.

Bahl, M. (2003). Conteúdos culturais e naturais em roteiros turísticos versus artificialismo induzido. In M. Bahl (Org.). Turismo: enfoques teóricos e práticos (pp. 141-148). São Paulo: Roca.

Bahl, M. (2009). Dimensão cultural do turismo étnico. In A. P. Netto, e M. G. dos R. Ansarah, (Eds.). Segmentação do mercado turístico (121-140). Barueri: Manole

Barretto, M. (2005). Turismo étnico y tradiciones inventadas. In A. Santana Talavera e L. Prats Canals (Coords.). El encuentro del turismo con el patrimonio cultural: concepciones teóricas y modelos de aplicación (pp. 39-56). Sevilla: FAAEE- Fundación El Monte. 
Brasil. (1973, 21 de dezembro). Lei n. 6.001, de 19 de dezembro de 1973. Dispõe sobre o Estatuto do Índio. Diário Oficial da União, seção 1. Disponível en: <http://www.planalto.gov.br/ccivil_03/Leis/L6001.htm>. Consultado em: 28/11/2015.

Brasil. (1988, 5 de outubro). Constituição da República Federativa do Brasil de 1988. Disponível em: <http://www.planalto.gov.br/ccivil_03/constituicao/constituicao.htm>. Consultado em: 04/07/2015

Brasil. (1996, 9 de janeiro). Decreto n. 1.775, de 8 de janeiro de 1996. Dispõe sobre o procedimento administrativo de demarcação das terras indígenas e dá outras providências. Diário Oficial da União, seção 1. Disponível em: <http://www.planalto.gov.br/ccivil_03/decreto/D1775.htm>. Consultado em: 29/11/2015.

Bunten, A. C. (2014). Deriding demand: indigenous imaginaries in tourism. In N. B.Salazar e N. H. H. Graburn (Eds), Tourism imaginaries: anthropological approaches (pp. 80-102) New York, NY: Berghan.

CAPES - Cooperação de Aperfeiçoamento de Pessoal de Nível Superior. (2015). Banco de teses. Disponível em: <http://www.capes.gov.br/ component/content/article?id=2164>. Consultado em: 26/11/2015.

Chaves, R. P. R. (2012). O turismo étnico em comunidades indígenas $n$ Brasil: a Reserva Pataxó da Jaqueira e o Parque Indígena do Xingu. In R. H. Asensio e B. Pérez Galán (Eds.). ¿El turismo es cosa de pobres? Patrimonio cultural, pueblos indígenas y nuevas formas de turismo en América Latina (pp. 115-129). El Sauzal, Tenerife: ACA y PASOS, RTPC. Disponível em: <http://www.pasosonline.org/Publicados/pasosoedita/PSEdita8.pdf>. Consultado em: 01/04/2016.

Costa, F. R. (2009). Turismo e patrimônio cultural: interpretação e qualificação. São Paulo: SENAC.

Faria, I. F. de. (2005). Ecoturismo: etnodesenvolvimento e inclusão social no Amazonas. PASOS Revista de Turismo y Patrimonio Cultural, 3(1), 63-77. Disponível em: <http://www.pasosonline.org/Publicados/3105/PS040105.pdf>. Consultado em: 28/02/2016.

Faria, I. F. de. (2008). Ecoturismo indígena - território, sustentabilidade, multiculturalismo: princípios para a autonomia. (Tese de Doutorado). Faculdade de Filosofia, Letras e Ciências Humanas, Universidade de São Paulo. São Paulo, Brasil. Disponível em: <http://www.teses.usp.br/teses/disponiveis/8/8135/tde-17022011-095412/pt-br.php>. Consultado em: 30/03/2016.

Fortunato, R. A. e Silva, L. S. (2013). Os conflitos em torno do Turismo Comunitário na Prainha do Canto Verde (CE). Revista Brasileira de Ecoturismo, 6(1), 123-138. Disponível em:

<http://www.sbecotur.org.br/rbecotur/seer/index.php/ecoturismo/article/view/481/418 >. Consultado em: 28/03/2016.

Graburn, N. (1992). Turismo: el viaje al sagrado, In V. L. Smith, Pardo, J., e Martínez-Lage (Trad.), Anfitriones e invitados: antropologia del turismo (pp. 45-68). Madrid: Endymion.

Graburn, N. (2009). Antropologia ou Antropologias do Turismo? In R. de A. Grünewald; N. Graburn,; M. Barretto; C. A.; Steil e R. J. dos Santos (Orgs.). Turismo e antropologia: novas abordagens (pp. 13- 52). São Paulo: Papirus.

Greenwood, D. J. (1992). La cultura al peso: perspectiva antropológica del turismo en tanto proceso de mercantilizacion cultural. In V. L. Smith (Ed), Pardo, J., e Martínez-Lage 
(Trad.), Anfitriones e invitados: antropologia del turismo (pp. 257-279). Madrid: Endymion.

Grünewald, R. de A. (1999). Os "Índios do Descobrimento": tradição e turismo. (Tese de Doutorado em Antropologia Social). Universidade Federal do Rio de Janeiro/Museu Nacional, Rio de Janeiro. Disponível em: <http://indiosnonordeste.com.br/wpcontent/uploads/2012/08/TESE-SOBRE-OSPATAX\%C3\%93-BAHIA.pdf>. Consultado em: 04/11/2015.

Grünewald, R. de A. (2002). Tourism and cultural revival. Annals of Tourism Research, 29(4), $1004-1021$.

Guimarães, R. G. (2006). Turismo em terras indígenas já é fato: quem se arrisca? Revista Dialogando no Turismo, 1, 15-42. Disponível em: <http://www.rosana.unesp.br/revista/documentos/v1n1a2.pdf>. Consultado em: 01/04/2016.

Harkin, M. (1995). Modernist anthropology and tourism of the authentic. Annals of Tourism Research, 22(3), 650-670.

Harvey, D. (1996). Condição pós-moderna. São Paulo: Edições Loyola.

Hinch, T.D. e Butler, R (1996). Introduction. In R. Butler e Tom Hinch (Eds.). Tourism and indigenous peoples (pp. 1-14). Thomson: Londres.

Hinch, T. D. (2004). Indigenous people and tourism. In C.Lew; M. Hall; A. M. Williams, (Eds). A companion to tourism (pp. 246-258). Malden, MA: Blackwell.

Jesus, D. J. de. (2012). A (re)tradicionalização dos territórios indígenas pelo turismo: um estudo comparativo entre os Kadiwéu (Mato Grosso do Sul- BR) e Maori (Ilha Norte NZ). (Tese de Doutorado em Geografia). Universidade Federal do Paraná. Curitiba, Brasil. Disponível em: <http://dspace.c3sl.ufpr.br/dspace/bitstream/handle/1884/27396/R\%20-\%20T\%20-

\%20JESUS,\%20DJANIRES\%20LAGEANO\%20DE.pdf?sequence $=1>$. Consultado em: 04/03/2016.

Lac, F. (2004). O turismo e os Kaingang na Terra Indígena de Iraí/RS. (Dissertação de Mestrado). Universidade Federal do Paraná. Curitiba, Brasil. Disponível em: <http://www.dominiopublico.gov.br/download/texto/cp029037.pdf>. Consultado em 30/03/2016.

Lacerda, M. A. (2004). Perspectivas de desenvolvimento local entre os Terena, na Aldeia Urbana Marçal de Souza, em Campo Grande - MS: a opção pelo etnoturismo. (Dissertação de Mestrado). Universidade Católica Dom Bosco. Campo Grande, Brasil. Disponível em: <http://site.ucdb.br/public/md-dissertacoes/7946-perspectivas-dedesenvolvimento-local-entre-os-terena-na-aldeia-urbana-marcal-de-souza-em-campogrande-ms-a-opcao-pelo-etnoturismo.pdf>. Consultado em: 30/03/2016.

Leandro, E. L. (2011). Ecoturismo indígena e gestão territorial, contribuições participativas da terra indígena Paiterey Karah (Sete de Setembro). (Dissertação (Mestrado em Geografia). Universidade Federal de Rondônia. Porto Velho, Brasil.

Lei n. 6.001, de 19 de dezembro de 1973. (1973, 21 de dezembro). Dispõe sobre o Estatuto do Índio. Diário Oficial da União, seção 1. Disponible en: <http://www.planalto.gov.br/ccivil_03/Leis/L6001.htm>. Consultado em: 28/02/2016.

López Pardo, G.; Palomino Villavicencio, B. (2008). Politicas públicas y ecoturismo en comunidades indígenas de México. Teoria y Praxis, 5, 33-50. Disponível em: <http://www.teoriaypraxis.uqroo.mx/doctos/Numero5/Lopez-Palomino.pdf>.

Consultado em: 26/03/2016. 
Lustosa, I. M. C. (2012). Os povos indígenas, o turismo e o território: um olhar sobre os Tremembé e os Jenipapo-Kanindé do Ceará. (Tese de Doutorado em Geografia). Universidade Federal de Goiás. Goiânia, Brasil. Disponível em:

$<$ http://www.academicoo.com/artigo/os-povos-indigenas-o-turismo-e-o-territorio-umolharsobre-os-tremembe-e-os-jenipapo-kaninde-do-ceara/>. Consultado em: 04/12/2015.

Martínez Cobo, J. R. (1986). Study of the problem of discrimination against indigenous populations. ( No. UN-Document E/CN. 4 Sub.). New York, NY: United Nations. Subcommission on Prevention of Discrimination and Protection of Minorities. Disponível em:

$<$ http://undesadspd.org/IndigenousPeoples/LibraryDocuments/Mart\%C3\%ADnezCoboS tudy.aspx>. Consultado em: 07/11/2015.

Molina, S. (2003). O pós-turismo. São Paulo: ALEPH.

Morales González, M. (2008) ¿Etnoturismo o turismo indígena? Teoría y Praxis, 5, 123-136.

Disponível em: <http://www.teoriaypraxis.uqroo.mx/doctos/Numero5/Morales.pdf>. Consultado em: 30/03/2016.

Neves, S. C. (2012). A apropriação indígena do turismo: os Pataxó de Coroa Vermelha e a expressão da tradição. (Tese de Doutorado em Antropologia). Faculdade de Filosofia e Ciências Humanas, Universidade Federal da Bahia. Salvador, Brasil.

Nunes, R. G. A. (2006). O turismo como prática social em território indígena: uma análise comparativa entre a Reserva Indígena de Dourados-MS e a aldeia Puiwa Poho em Feliz Natal-MT. (Dissertação de Mestrado em Geografia). Universidade Federal de Mato Grosso do Sul. Aquidauana, Brasil. Disponível em: <http://livros01.livrosgratis.com.br/cp120114.pdf>. Consultado em: 02/02/2016.

OIT - Organização Internacional do Trabalho (2011). Convenção $n^{\circ} 169$ sobre povos indígenas $e$ tribais e Resolução referente à ação da OIT. Brasília: OIT. Disponível em: $<$ http://portal.iphan.gov.br/baixaFcdAnexo.do?id=3764>. Consultado em: 28/06/2015.

<http://www.teses.usp.br/teses/disponiveis/8/8136/tde-04062007-160917/pt-br.php>. Consultado em: 30/11/2015.

Oliveira, A. M. de e Jesus, D. L. de. (2010). Territórios étnicos: narrativas de um processo participativo para o desenvolvimento da atividade turística. Cultur, Revista de Cultura e Turismo, 4(1), 59-75.

Disponível em: <http://www.uesc.br/revistas/culturaeturismo/edicao7/artigo_5.pdf>. Consultado em: 30/03/2016.

Oliveira, V. M. de. (2006). Turismo, território e modernidade: um estudo da população indígena Krahô, Estado do Tocantins (Amazônia Legal Brasileira). (Tese de Doutorado). Faculdade de Filosofia, Letras e Ciências Humanas, Universidade de São Paulo. São Paulo, Brasil. Disponível em: <http://www.teses.usp.br/teses/disponiveis/8/8136/tde04062007-160917/pt-br.php>. Consultado em: 30/03/2016.

ONU - Organização das Nações Unidas. (1996). Actividades normativas: evolucion de las normas relativas a los derechos de los pueblos indígenas. Documento de trabajo de la Relatora Especial Erica-Irene A. Daes sobre el concepto de Pueblos Indígenas. (No. E/CN.4/Sub.2/AC.4/1996/2). New York: United Nations. Commision of Human Rights. Disponível em: <http://daccess-ddsny.un.org/doc/UNDOC/GEN/G96/129/83/PDF/G9612983.pdf?OpenElement>.

Consultado em: 28/02/2016. 
Palomino Villavicencio, B.e López Pardo, G. (2011). Ecoturismo indígena en Quintana Roo, Mexico - Estudio de caso Kantemo. Encontros Científicos - Tourism \& Management Studies, n. Extra 1 (Proceedings International Conference Tourism \& Management Studies 2011), Algarve, 990-998. Disponível em: <https://dialnet.unirioja.es/servlet/articulo?codigo=5018499>. Consultado em:14/03/2016.

Pereiro Pérez, X. (2009). Turismo cultural: uma visão antropológica. El Sauzal, Tenerife: ACA y PASOS, RTPC. Disponível em: <http://www.pasosonline.org/Publicados/pasosoedita/PSEdita2.pdf>. Consultado em: 30/03/2016.

Pereiro Pérez, X. (2014). Reflexión antropológica sobre el turismo indígena. Desacatos, v. 47(4),18-35. Disponível em: <http://www.scielo.org.mx/pdf/desacatos/n47/n47a2.pdf>. Consultado em: 14/03/2016.

Pereiro Pérez, X.; Leon, C. de; Martínez Mauri, M.; Ventocilla, J. e Del Valle, Y. (2012). Los turistores Kunas: antropología del turismo étnico en Panamá. Palma, Espanha: Universitat de lês llles Balears. Disponível em: <https://www.yumpu.com/es/document/view/23354980/los-turistores-kunasantropologia-del-turismo-etnico-en-panama>. Consultado em: 01/04/2016.

Ramos, K. V. (2008). A construção do espaço turístico: trocas simbólicas entre turistas e comunidade Tupinambá em Olivença (Ilhéus - BA). ( Dissertação de Mestrado em Turismo e Cultura). Universidade Estadual de Santa Cruz/ Universidade Federal da Bahia. Ilhéus, Brasil. Disponível em:

$<$ http://www.uesc.br/cursos/pos_graduacao/mestrado/turismo/dissertacao/karen_ramos_ pdf.pdf>. Consultado em: 04/03/2016.

Ribeiro, D. (1957). Línguas e culturas indígenas do Brasil. Rio de Janeiro: Centro Brasileiro de Pesquisas Educacionais.

Ryan, C. (2005). Introduction: tourist-host nexus - research considerations. In C. Ryan e M. Aicken (Eds.). Indigenous tourism: the commoditificacion and management of culture (pp. 1-11). Oxford: Elsevier.

Sampaio, C. A. C.; Fernandes, V. e Philippi Junior, A. (2010). Planejamento e gestão de turismo comunitário sustentável: metodologia PEC e SiGOS. In A. Philippi Junior e D. V. de M. Ruschmann, (Eds.). Gestão ambiental e sustentabilidade no turismo (pp. 151-171). Barueri, SP: Manole.

Santana Talavera, A. (2003). Turismo cultural, culturas turísticas. Horizontes Antropológicos, 9(20),31-57. Disponível em: <http://www.scielo.br/pdf/ha/v9n20/v9n20a02.pdf>. Consultado em: 30/03/2016.

Santos, L. C. (2010). Sahu-Apé e o turismo em Terras e comunidades indígenas. 255 p. Dissertação (Mestrado em Antropologia Social), Universidade Federal do Amazonas, Manaus, Disponível em: <http://www.ppgas.ufam.edu.br/ attachments/article/31/Disserta\%C3\%A7\%C3\%A30\%20-\%20Luciano\%20Cardenes \%20\%20Sahu-Ap\%C3\%A9.pdf>. Consultado em: 04/07/2015.

Smith, M. K. (2003). Issues in Cultural Tourism Studies. London: Routledge.

Smith, V. L. (1992). Introducción. In V. L. Smith (Ed), Pardo, J., e Martínez-Lage (Trad.), Anfitriones e invitados: antropologia del turismo. M. Madrid: Endymion.

Smith, V. L. (1996). Indigenous Tourism: The Four Hs. In R. Butler y T. Hinch (Eds.). Tourism and Indigenous Peoples (pp. 283-307). London: International Thomson. 
Swain, M. B. (1992). Roles de genero en el turismo indigenista: las molas de los Kunas, Kuna Yala y la supervivencia cultural. In V. L. Smith (Ed), Pardo, J., e Martínez-Lage (Trad.), Anfitriones e invitados: antropologia del turismo (pp. 139-169). Madrid: Endymion.

Swarbrooke, J. e Horner, S. (2011). O comportamento do consumidor no turismo. São Paulo: Aleph.

Thomson-Carr, A. (2013). Mãori Tourism: A Case Study of managing indigenous cultural values. In M. Smith y G. Richards (Eds.). The routledge handbook of cultural tourism (pp. 227-235). Londres: Routledge.

Torres, R. (2002). Cancun's tourism development from a Fordist spectrum of analysis. Tourism Studies, 2(1), 87-116.

van den Berghe, P. L. (1995). Marketing Mayas: Ethnic tourism promotion in Mexico. Annals of Tourism Research, 22(3), 568-588.

van den Berghe, P. e Keyes, C. F. (1984). Introduction tourism and re-created ethnicity. Annals of Tourism Research, 11(3), 343-352.

Zeppel, H. (2006). Indigenous ecotourism: sustainable development and management. (3 Ed.) Cambridge: Kabi. Ecotourism Series.

Para citar este artículo: Corbari, S.D.; Bahl, M. y de Souza, S.R (2016). Reflexões sobre conceitos e definições atinentes ao turismo envolvendo comunidades indígenas. Investigaciones Turísticas, (12), $50-72$. http://dx.doi.org/10.14198/INTURI2016.12.03 